\title{
GINGIVAL RECESSION: PREVALENCE, EXTENSION AND SEVERITY IN ADULTS
}

\author{
RECESSÃO GENGIVAL: PREVALÊNCIA, EXTENSÃO E SEVERIDADE EM ADULTOS
}

Milena Guerreiro MARINI ${ }^{1}$, Sebastião Luiz Aguiar GREGHI², Euloir PASSANEZI ${ }^{3}$, Adriana Campos Passanezi SANT’ANA ${ }^{2}$

1- DDS, MSc, Master in Periodontology.

2- DDS, MSc, PhD, Assistant Professor of the Department of Prosthodontics, Discipline of Periodontology, Bauru Dental School,

University of Sao Paulo, Bauru, Sao Paulo, Brazil.

3- DDS, MSc, PhD, Associate Professor of the Department of Prosthodontics, Discipline of Periodontology, Bauru Dental School,

University of Sao Paulo, Bauru, Sao Paulo, Brazil.

Corresponding address: Milena Guerreiro Marini - Rua Paulo Guerreiro Franco, 120 - Centro - Vera Cruz - SP - 17560-000

Tel.: (14) 3492-1560 - email: mgmarini@bol.com.br

Received: September 15, 2003 - Returned for modification: October 23, 2003 - Accepted: January 16, 2004

\begin{abstract}
$T$

1 he gingival recession was assessed in 380 adult individuals aged more than 20 years and comprised both subjects being treated and looking for treatment at Bauru Dental School. Clinical evaluation was conducted by a single examiner in all teeth and involved analysis of four dental aspects (mesial, buccal, distal and lingual). The gingival recession was regarded as present whenever more than $1 \mathrm{~mm}$ of root surface was exposed, and its vertical width was measured in millimeters from the cementoenamel junction to the gingival margin. The recessions were further scored following the criteria suggested by Miller in 1985. Gingival recession was observed in at least one dental surface in about $89 \%$ of the individuals analyzed. The prevalence, extension and severity of this clinical aspect increased with age. Class I recessions were the most frequent, yet there was a gradual increase of Class III and IV recessions as older subjects were evaluated. The mandibular teeth displayed more surfaces with gingival recession than the maxillary teeth and the mandibular incisors were the most affected teeth. Such high prevalence of gingival recession in adult patients demonstrates that dental professionals should provide attention to the clinical relevance of such alterations, as well as to the diagnosis of the etiologic factors.

Uniterms: Gingival recession, epidemiology.
\end{abstract}

\section{RESUMO}

$R$

ecessão gengival foi relatada em 380 indivíduos adultos com mais de 20 anos de idade, pacientes em tratamento ou indivíduos que procuravam atendimento odontológico na Faculdade de Odontologia de Bauru. Durante avaliação clínica, realizada por apenas um examinador, em todos os dentes, quatro superfícies foram consideradas (mesial, vestibular, distal e lingual). Recessão gengival foi considerada presente quando mais de 1mm de raiz estivesse exposta e sua amplitude vertical foi medida em milímetros da junção cemento-esmalte a margem gengival. As recessões foram ainda classificadas segundo os parâmetros da classificação proposta por Miller, em 1985. Recessão gengival foi encontrada em pelo menos uma superfície dentária em aproximadamente 89\% dos indivíduos avaliados. A prevalência, extensão e severidade desta condição clínica aumentaram com o avanço da idade. As recessões classe I foram as mais freqüentes, mas houve um aumento gradual das recessões classe III e IV à medida que indivíduos mais idosos foram avaliados. Os dentes inferiores tiveram mais superfícies com recessão do que os superiores, e os mais freqüentemente envolvidos foram os incisivos inferiores. Diante da elevada prevalência de recessão gengival em adultos, os cirurgiões-dentistas devem estar atentos à importância clínica destas alterações e ao diagnóstico de seus fatores causais.

Unitermos: Recessão gengival, epidemiologia. 


\section{INTRODUCTION}

Gingival recession, commonly observed in adult subjects, has been defined as a clinical condition on which the marginal periodontal tissue is located apical to the cementoenamel junction (CEJ) with concomitant exposure of the root surface ${ }^{30}$, a clinical feature that explains its simplified and common designation as root exposure.

Despite the frequent observation in adult subjects, the prevalence, extension and severity of gingival recessions presents considerable differences between study populations. Prevalence indicates the cases or occurrences of gingival recession; extension corresponds to the number of teeth affected by such alterations; and severity denotes the amount of root surface exposed by the recession, i.e. the linear vertical width of the marginal alteration. Gingival recession in the USA has been reported in 78 to $100 \%$ of middle-aged individuals, affecting 22 to $53 \%$ of the teeth ${ }^{8}$. In Oslo, Norway, 51\% of the adult subjects aged more than 18 years had gingival recession ${ }^{19}$. In New Guinea, 11 to $40 \%$ of the adult individuals presented gingival recession ${ }^{20}$. In Finland, $68 \%$ of the subjects displayed such alterations, affecting $11 \%$ of the teeth ${ }^{28}$.

The concern on these alterations is based on the potential consequences they may bring about, which affect not only oral health but also the general health. Within this context, the clinical relevance of gingival recession has been related to several conditions such as cervical dentin hyperesthesia ${ }^{1}$; esthetic distress, especially when such lesions affect the anterior teeth; higher risk of root caries and abrasion and/or erosion lesions because of exposure of the root surface to the oral environment, besides an increase in the accumulation of dental plaque ${ }^{26}$.

In addition to all clinical implications associated to the presence of gingival recession, such alterations have been regarded as the clinical manifestation of the periodontal attachment loss and may be an important aspect in the diagnosis of susceptibility to periodontal disease ${ }^{4}$. Thus, perception of the occurrence of gingival recession in a given population is a basic need for their prevention and control and allows the proper planning of health centers based on information on the prevalence and severity of these lesions, in order to establish proper and effective preventive programs that may control the onset and/or progression of gingival recession, as well as to avoid the complex local disturbances that may develop.

Therefore, the present study aimed at assessing the prevalence, extension and severity of gingival recessions in adult subjects attending Bauru Dental School.

\section{MATERIALAND METHODS}

The study sample comprised 380 adult subjects aged more than 20 years old, randomly selected from the patients attending the clinics of Bauru Dental School/USP, or among patients looking for dental treatment at this institution by means of the Screening sector. All participants were informed on the evaluation to which they would be submitted and signed an informed consent term for participation in the study. The subjects of both genders were divided in 4 groups according to the age range:

Group $1-20$ to 29 years: 100 patients;

Group $2-30$ to 39 years: 100 patients;

Group 3-40 to 49 years: 100 patients;

Group 4 - above 50 years: 80 patients.

The selection criteria comprised age above 20 years and a mean number of 20 natural teeth, since large numbers of missing teeth might interfere with the results of this study.

The participants of the present study were evaluated by a single examiner, who was not submitted to any previous calibration.

The sample included 234 women and 146 men, adding up to 9,379 teeth. A millimetered periodontal probe marked up to $15 \mathrm{~mm}$, model Color Coded Probe, code CP-15UNCPCPUNC15, Hu-Friedy, was employed for evaluation of the teeth of each subject by a single examiner, concerning the presence of gingival recession, which was recorded whenever there was more than $1 \mathrm{~mm}$ of root surface exposed. Four surfaces were evaluated in each tooth: mesial, buccal, distal and lingual, and linear measurements were obtained from the cementoenamel junction up to the gingival margin in the teeth presenting with gingival recession, in order to evaluate the vertical (apicocoronal) width of the recession. In cases on which the cementoenamel junction was covered by calculus, hidden by a restoration or lost due to wear or carious lesions, the location of such junction was estimated on the basis of the adjacent teeth. Three categories were established according to the apicocoronal dimension of the root surface exposed by the gingival recession: small recessions - less than $3 \mathrm{~mm}$ of root surface exposed; moderate recessions -3 to $4 \mathrm{~mm}$ of root surface exposed; advanced recessions - more than $4 \mathrm{~mm}$ of root surface exposed to the oral environment. The recessions were further scored according to the system suggested by Miller ${ }^{16}$ in 1985.

\section{RESULTS}

Gingival recession was observed in 338 subjects out of all subjects aged more than 20, corresponding to almost $89 \%$ of the sample. From these individuals, 3,526 displayed root surface exposure $=1 \mathrm{~mm}$, corresponding to almost $38 \%$ of all teeth evaluated and adding up to 6,123 sites with gingival recession (Table 1 ).

Among the subjects without any such alterations, more than $85 \%$ belonged to the younger age range (20-29 years). This differed from the two older groups of the sample, on which almost all subjects presented with gingival recession (Table 1).

The increase in age led to an increase in the mean number of teeth with gingival recession (Table 1 ); thus, the subjects presenting more teeth with these alterations aged more than 50 years and had more than $60 \%$ of their teeth affected (Table 1). 
The mandibular central incisors were the teeth most frequently affected by root surface exposure, even though the mandibular premolars and maxillary first molars also commonly displayed gingival recession (Figure 1).

As regards the apicocoronal length of the gingival recessions observed on the different age ranges, the vertical width of the root surfaces exposed increased as older subjects were assessed (Figure 2).

Scoring of the gingival recessions at the buccal aspect according to the classification of Miller (1985) revealed that Class I recessions were the most prevalent, followed by Class III recessions (Table 2). Concerning the different age ranges, Class I recessions were also the most prevalent, yet its frequency was gradually decreased as age increased. On the other hand, Class IV recessions, regarded as the most severe according to the classification of Miller, displayed an increasing occurrence with the increase in age (Table 2).

\section{DISCUSSION}

The results of the present investigation corroborate previous findings of the common occurrence of gingival recession in adult subjects.

As observed in most epidemiological studies ${ }^{2,8,12,28}$, the prevalence, extension and severity of gingival recession gradually increased with age. In the younger group, 64\% of the subjects had gingival recession, which displayed a mean vertical width of $1.04 \mathrm{~mm}( \pm 0.92)$ and comprised about $14 \%$ of all teeth evaluated in this age range; moreover, more than $70 \%$ of these individuals presented just recessions smaller than 3mm. On the other hand, almost 99\% of the subjects aged more than 50 years presented with gingival recession, which had a mean vertical width of $2.16 \mathrm{~mm}( \pm 0.79)$ and comprised more than $60 \%$ of the teeth in this group. It should be highlighted that more than $40 \%$ of the subjects in this age range had at least one tooth with gingival recession larger than $4 \mathrm{~mm}$.

This relationship between the occurrence of gingival recession and age may probably be because of the longer period of exposure to the agents that cause gingival recession ${ }^{11,18}$, associated to intrinsic changes in the organism, both local and systemic ${ }^{22}$, besides the cumulative effects of the lesion itself ${ }^{21}$.

TABLE 1- Prevalence and extension of gingival recession according to age group

Gingival recession $\geq 1 \mathrm{~mm}$

\begin{tabular}{llllllll}
\cline { 3 - 7 } & & \multicolumn{2}{c}{ Prevalence } & & \multicolumn{3}{c}{ Extension } \\
\cline { 3 - 7 } Age (years) & $\begin{array}{c}\text { Number } \\
\text { of subjects }\end{array}$ & $\begin{array}{l}\text { Number } \\
\text { of teeth }\end{array}$ & \% Subjects & $\begin{array}{c}\text { Number } \\
\text { of teeth }\end{array}$ & $\begin{array}{c}\text { Mean } \\
\text { number of } \\
\text { teeth/ } \\
\text { subjects }\end{array}$ & $\begin{array}{c}\text { Number } \\
\text { of sites }\end{array}$ & $\begin{array}{c}\text { Mean } \\
\text { number of } \\
\text { sites/ } \\
\text { subjects }\end{array}$ \\
\hline $20-29$ & 100 & 2682 & 64 & 374 & 3.7 & 465 & 4.7 \\
$30-39$ & 100 & 2521 & 96 & 876 & 8.8 & 1350 & 13.5 \\
$40-49$ & 100 & 2405 & 99 & 1199 & 12.0 & 2165 & 21.7 \\
$\geq 50$ & 80 & 1771 & 98.8 & 1077 & 13.5 & 3143 & 26.8 \\
TOTAL & 380 & 9379 & 89 & 3526 & 9.3 & 6123 & 16.1 \\
\hline
\end{tabular}

TABLE 2- Scoring of the severity of gingival recession according to the parameters of Miller

Gingival Recession

\begin{tabular}{llllllllll}
\hline & \multicolumn{10}{c}{ Gingival Recession } \\
\cline { 2 - 10 } Age (yrs) & \multicolumn{2}{c}{ Class I } & \multicolumn{1}{c}{ Class II } & Class III & Class IV & TOTAL \\
\hline \multirow{2}{*}{$20-29$} & 209 & $81.64 \%$ & 11 & $4.30 \%$ & 33 & $12.89 \%$ & 3 & $1.17 \%$ & 256 \\
$30-39$ & 455 & $67.61 \%$ & 17 & $2.53 \%$ & 176 & $26.15 \%$ & 25 & $3.71 \%$ & 673 \\
$40-49$ & 565 & $58.43 \%$ & 25 & $2.59 \%$ & 342 & $35.37 \%$ & 35 & $3.62 \%$ & 967 \\
$\geq 50$ & 445 & $47.64 \%$ & 26 & $2.78 \%$ & 369 & $39.51 \%$ & 94 & $10.06 \%$ & 934 \\
TOTAL & 1674 & $59.15 \%$ & 79 & $2.79 \%$ & 920 & $32.51 \%$ & 157 & $5.55 \%$ & 2830 \\
\hline
\end{tabular}


Despite the controversies regarding the etiology of root surface exposure, recession of the gingival margin may probably indicate the occurrence of a local inflammatory process in different stages, possibly triggered by a physical, chemical or bacterial aggresion ${ }^{3,17}$. Such condition is frequently reported as the combination of several factors classified in two major groups: factors predisposing to the area and occurrence of gingival recession - called predisposing factors; and factors that lead to onset of the disturbance - named precipitating factors, in charge of the induction of gingival recession.

The main precipitating factors of gingival recession described in the literature are bacterial plaque ${ }^{7}$, mechanical trauma related to the employment of hard-bristled toothbrushes, ${ }^{11}$ technique $^{6}$ and frequency of toothbrushing ${ }^{28}$, orthodontic therapy ${ }^{24}$ and chemical trauma, primarily related to smoking ${ }^{14}$.

However, besides the presence of precipitating factors, conditions that favor destruction of the marginal tissue must also be present for the occurrence of gingival recession. Such conditions are referred to on the literature as predisposing factors and are defined as local anatomic characteristics that favor the occurrence of gingival alterations, such as: functionally unsatisfactory quantity and quality of attached gingiva, ${ }^{10}$ bone dehiscence ${ }^{13}$, buccal tipping $^{8,17,25}$, high frenum attachment ${ }^{25}$ and traumatic occlusion $^{17,23,25,29}$.

The occurrence of gingival recession in young patients is usually localized and seems to comprise isolated etiologic factors. On the other hand, a more generalized distribution, as observed among older subjects, might indicate the associated and cumulative effect of several factors ${ }^{21}$ such as previous periodontal disease associated to toothbrushing trauma.

The interrelation between the primary pathogenic process - related to the bacterial, mechanical or chemical aggression - and the local anatomic factors is also remarkably important, since the latter may induce not only the formation but also the quality and morphology of the lesions ${ }^{17}$.

Within this context, the severity of gingival recessions, commonly assessed by the extension of root surface exposure, may be evaluated through the classification suggested by Miller $^{16}$ in 1985, which also allows inferences as to the predictability of the therapy established in this area, especially concerning the possibility to recover the root surface exposed. Class I recessions, the prognosis of which is quite favorable,

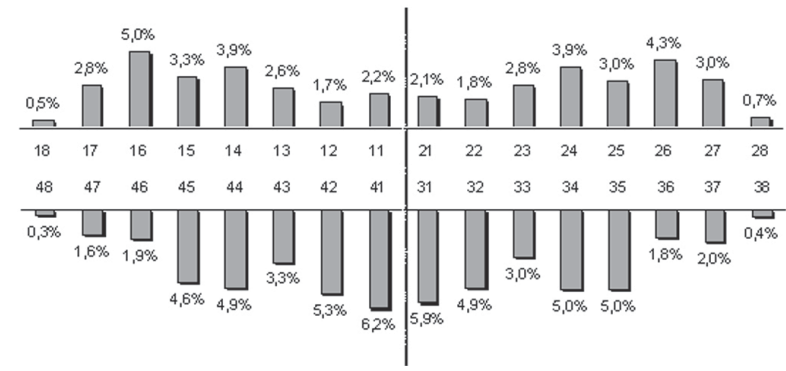

FIGURE 1- Intraoral distribution of gingival recession were the most prevalent in all age ranges. On the other hand, Class III and IV recessions, regarded as the most severe with the worst prognosis, had an increasingly larger prevalence in older subjects.

There was a higher prevalence of recession in the mandibular teeth (56.33\%), as observed in previous investigations ${ }^{28}$, even though GORMAN observed a similar prevalence (56\%) on the maxilla ${ }^{8}$, which the author assigned to thin or absent buccal plates.

The larger occurrence of gingival recessions in the mandibular teeth is probably related to the characteristics of the keratinized mucosa, which is wider ${ }^{5}$ and also probably thicker in the maxilla than in the mandible, since a strong correlation has been observed between the quantity and quality of gingival tissue ${ }^{15}$. Areas with deficient keratinized mucosa, especially as regards the thickness, have been demonstrated to be more susceptible to gingival recession, especially due to the smaller amount of connective tissue available on the area, what leads localized inflammatory reactions triggered by different processes to be able to affect the entire extension of the tissue, ultimately leading to gingival recession $^{3,7,10,17}$.

No differences were observed in the occurrence of gingival recession at the right and left sides, in agreement with the findings of Vehkalathi ${ }^{28}$. This result seems to indicate the lack of variation in the toothbrushing between individuals, either right- or left-handed, in relation to the traumatic effects of toothbrushing.

As regards the teeth most frequently affected by gingival recession, no consensus is observed in the literature. Whereas some indicate the maxillary canines and premolars ${ }^{1,8}$, other mention maxillary premolars and molars ${ }^{9,21}$ and others indicate the mandibular central incisors and maxillary first molars ${ }^{2}$ as the teeth most frequently affected by these alterations. In the present study, the mandibular central incisors displayed the highest frequency of gingival recession. The mandibular lateral incisors and premolars and the maxillary first molars and first premolars were also commonly affected.

It should be stressed that the distribution pattern of gingival recessions has been related to different etiologic factors. Gingival recessions on the mandibular incisors have been primarily associated to poor oral hygiene ${ }^{27}$, whereas those on the premolars would be originated by traumatic toothbrushing ${ }^{9}$. Concerning the maxillary first molars, some authors believe the cause would be traumatic

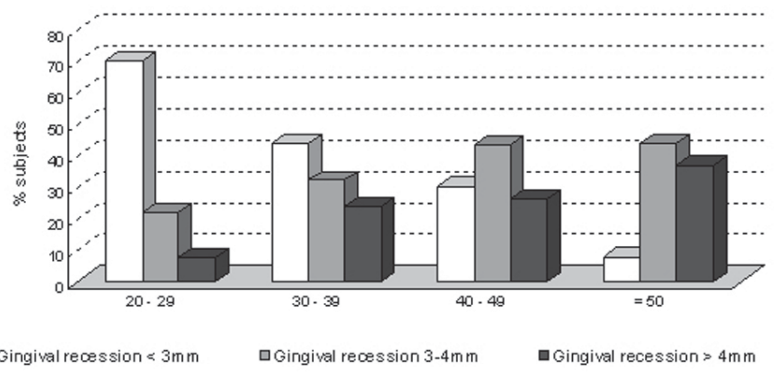

FIGURE 2- Severity of gingival recession according to age groups 
toothbrushing ${ }^{18,19}$, whereas others state that it would be the outcome of a poor oral hygiene, demonstrated by the presence of dental plaque and calculus. These disagreements question the cause-effect relationship between gingival recession and dental calculus: would calculus be the etiologic factor or the consequence of gingival recession?

Even though dental calculus is aggressive to the periodontal tissues, especially because of the additional retention it provides to the accumulation of dental plaque and consequent periodontal destruction as indicated by the gingival recession itself, its presence in sites with gingival recession is believed to be a consequence rather than a cause of root surface exposure, since surfaces with gingival recession are less favorable to self-cleansing than those without such alterations ${ }^{9}$. After accumulation in these areas, calculus might then act as a contributing factor in the progression and destruction of the marginal gingival tissue, yet probably it would not lead to onset of the process. It should be emphasized that localized gingival recession was often observed in teeth that apparently did not displayed plaque and calculus, especially in patients with good oral hygiene.

Despite the disagreement concerning the main tooth affected by gingival recession, the literature is unanimous to indicate the buccal surface as the site most frequently affected by such alterations ${ }^{2,8}$, in agreement with the present study. The occurrence of recession in these areas has been primarily associated to improper toothbrushing habits, whereas localized root surface exposures in the lingual and proximal aspects have been correlated to poor oral hygiene ${ }^{12}$.

Even though the distribution pattern of gingival recessions may provide significant indication of the main etiologic factor involved, it is not conclusive in the identification of the causes of such lesions; they must be correlated with several data before final diagnosis is achieved. This is not always simple and is often conducted through exclusion of the predisposing and precipitating factors that might be involved. Moreover, an association of these factors frequently leads to the occurrence of gingival recession, and therefore one factor may be the main, but not the only aspect leading to this alteration.

The high prevalence of gingival recession in adult subjects provides information to the dental professionals as to the importance of the diagnosis and knowledge on these alterations. The higher prevalence, extension and severity observed in older subjects, in turn, suggests the cumulative effect of the lesion, associated to the longer period of exposure to the etiologic agents, which should be identified and removed as early as possible in order to reduce or even avoid worsening of the clinical condition.

\section{ACKNOWLEDGEMENTS}

The authors would like to thank Dr. Jose Roberto Pereira Lauris for the statistical analysis.

\section{REFERENCES}

1- Addy M, Mostafa P, Newcombe RG. Dentine hypersensitivity: the distribution of recession, sensitivity and plaque. J Dent 1987 Dec; 15(6):242-8.

2- Albandar JM, Kingman A. Gingival recession, gingival bleeding and dental calculus in adults 30 years of age and older in the United States, 1988-1994 - National Institute of Dental and Craniofacial Research, National Institutes of Health. J Periodontol 1999 Jan; 70 (1):30-43.

3- Baker DL, Seymour GJ. The possible pathogenesis of gingival recession. A histological study of induced recession in the rat. J Clin Periodontol 1976 Nov; 3(4):208-19.

4- Beck JD, Koch GG. Characteristics of older adults experiencing periodontal attachment loss as gingival recession or probing depth. J Periodontal Res 1994 Jul; 29(4):290-8

5- Bowers GM. A study of the width of attached gingiva. J Periodontol 1963 May; 34:201-9.

6- Checchi L, Daprile G, Gatto MRA, Pelliccioni A. Gingival recession and toothbrushing in an Italian School of Dentristy: a pilot study. J Clin Periodontol 1999 May; 26(5):276-80.

7- Ericsson I, Lindhe J. Recession in sites with inadequate width of the keratinized gingiva. An experimental study in the dog. J Clin Periodontol 1984 Feb; 11(2):95-103.

8- Gorman WJ. Prevalence and etiology of gingival recession. J Periodontol 1967 Jul/Aug; 38(4):50/316-22.

9- Joshipura KJ, Kent RL, DePaola PF. Gingival recession: intra-oral distribution and associated factors. J Periodontol 1994 Sept; 65(9):864-71.

10- Kennedy JE, Bird WC, Palcanis KG, Dorfman HS. A longitudinal evaluation of varying widths of attached gingiva. J Clin Periodontol 1985 Sept; 12(8):667-75.

11- Khocht A, Simon G, Person P, Denepitiya JL. Gingival recession in relation to history of hard toothbrush use. J Periodontol 1993 Sept; 64(9):900-5

12- Löe H, Ånerud Å, Boysen H. The natural history of periodontal disease in man: prevalence, severity and extent of gingival recession. J Periodontol 1992 Jun; 63(6):489-95.

13- Löst C. Depth of alveolar bone dehiscences in relation to gingival recessions. J Clin Periodontol 1984 Oct; 11(9):583-589.

14- Martinez-Canut P, Lorca A, Magán R. Smoking and periodontal disease severity. J Clin Periodontol 1995 Oct; 22(10):734-49.

15- Mendonça JAG. Avaliação e análise das distâncias biológicas do periodonto mediante nova metodologia. Bauru, 2001. [Tese de Doutorado - Faculdade de Odontologia de Bauru, Universidade de São Paulo].

16- Miller Jr PD. A classification of marginal tissue recession. Int J Periodontics Restorative Dent 1985; 5(2):8-13.

17- Novaes AB, Rubens MP, Kon S, Goldman HM, Novaes Jr AB. The development of the periodontal cleft: a clinical and histopathologic study. J Periodontol 1975 Dec; 46(12):701-9.

18- O’leary TJ, Drake RB, Crump PP, Allen MF. The incidence of recession in young males: a further study. J Periodontol 1971 May; 42(5):264-7. 
19- Sangnes G, Gjermo P. Prevalence of oral soft and hard tissue lesions related to mechanical toothcleansing procedures. Community Dent Oral Epidemiol 1976 Mar; 4(2):77-83.

20- Schamschula RG, Keyes PH, Hornabrook RW. Root surface caries in Lufa, New Guinea. I. Clinical observations. J Am Dent Assoc 1972 Sept; 85(3):603-8.

21- Serino G, Wennström JL, Lindhe J, Eneroth L. The prevalence and distribution of gingival recession in subjects with a high standard of oral hygiene. J Clin Periodontol 1994 Jan; 21(1):57-63.

22- Ship JA, Beck, JD, Arbor A, Hill C. Ten-year longitudinal study of periodontal attachment loss in healthy adults. Oral Surg Oral Med Oral Path 1996 Mar; 81(3):281-90.

23- Solnit A, Stambaugh RV. Treatment of gingival clefts by occlusal therapy. Int J Periodontics Restorative Dent 1983; 3(3):38-55.

24- Steiner GG, Pearson JK, Ainamo J. Changes of the marginal periodontium as a result of labial tooth movement in monkeys. J Periodontol 1981 Jun; 52(6):314-20.

25- Trott JR, Love B. An analysis of localized gingival recession in 766 winnipeg high school students. Dent Pract Dent Rec 1966 Feb; 16(6):209-13.

26- Tugnait A, Clerehugh V. Gingival recession - its significance and management. Review. J Dent 2001 Aug; 29(6):381-94.

27- vanPalenstein Helderman WH, Lembariti BS, van der Weijden GA, van't Hof MA. Gingival recession and its association with calculus in subjects deprived of prophylactic dental care. J Clin Periodontol 1998 Feb; 25(2):106-11.

28- Vehkalahti M. Occurrence of gingival recession in adults. J Periodontol 1989 Nov; 60(11):599-603.

29- Watson PJC. Gingival recession. J Dent 1984 Mar; 12(1):29-35.

30- Wennström J, Piniprato GP. Terapia mucogengival. In: Lindhe, J. Tratado de periodontia clínica e implantologia oral. Rio de Janeiro: Guanabara Koogan; 1999. p.393-425. 